\title{
Karakteristik, Indiikasi, dan Temuan Endoskopi Saluran Cerna Atas pada pasien Anak
}

\author{
Deddy Satriya Putra
}

Bagian Ilmu Kesehatan Anak Fakultas Kedokteran Universitas Riau / RSUD Arifin Achmad, Pekanbaru

\begin{abstract}
Latar belakang. Pemeriksaan endoskopi saluran cerna pada anak sudah semakin berkembang dan telah banyak dilakukan di berbagai rumah sakit propinsi termasuk propinsi Riau. Berbagai penyakit saluran cerna pada anak diperlukan pemeriksaan endoskopi guna menemukan kelainan dan menentukan pengobatan yang tepat sehingga terjadinya penurunan angka kesakitan dan kematian

Tujuan. Mengetahui karakteristik, indikasi, dan temuan endoskopi saluran cerna atas pada pasien anak RSUD Arifin Achmad, Pekanbaru Riau.

Metode. Studi prospektif pada pasien pasien yang menjalani pemeriksaan endoskopi saluran cerna atas di Rumah Sakit Umum Daerah Arifin Achmad, Pekanbaru, dari bulan Agustus 2007 sampai dengan Agustus 2011.

Hasil. Didapat 87 pasien dilakukan pemeriksaan endoskopi saluran cerna atas (Gastroskopi) dengan usia terbanyak 5-10 tahun, indikasi berturut turut muntah darah, sakit perut berulang, muntah persisten, dan sakit perut akut dengan hasil temuan terbanyak berdasarkan indikasi berupa, gastroesofageal refluk, gastritis hiperemis, varises esophagus, dan gastritis akut. Dari 45 pasien yang dilakukan biopsi didapatkan $40(88,9 \%)$ pasien positif infeksi Helicobacter pylori.

Kesimpulan. Indikasi terbanyak dilakukan endoskopi saluran cerna atas (gastroskopi) pada anak adalah muntah darah dengan penyebab tersering berupa varises esofagus dan di antara 45 pasien didapatkan $88,9 \%$ infeksi Helicobacter pylori. Sari Pediatri 2013;15(1):61-4.
\end{abstract}

Kata kunci: endoskopi, gastroskopi, Helicobacter pylori ada dekade terakhir ini endoskopi saluran cerna merupakan alat diagnostik terpenting pada anak. ${ }^{1}$ Peningkatan pemeriksaan endoskopi saluran cerna menyebabkan pemeriksaan ini

Alamat korespondensi:

Dr. Deddy Satriya Putra, Sp.A(K). Staf Bagian Ilmu Kesehatan Anak FK.UNRI/RSUD Arifin Achmad Pekanbaru. Jalan Diponegoro no 2 Pekanbaru, Telp (0761) 858647, E-mail: dsatriyap@yahoo.com berkembang di banyak rumah sakit propinsi termasuk di Propinsi Riau. Penyakit gastrointestinal pada anak seperti sakit perut berulang, muntah darah, muntah persisten, diperlukan pemeriksaan endoskopi guna menemukan penyebab gangguan gastrointestinal sehingga pengobatan lebih tepat dengan harapan terjadinya penurunan angka kesakitan, dan angka kematian. ${ }^{2}$ Penelitian ini bertujuan untuk melihat karakteristik, indikasi, dan temuan endoskopi pada pasien anak yang 
Deddy Satriya Putra: Karakteristik, indikasi, dan temuan endoskopi saluran cerna atas

dilakukan endoskopi saluran cerna atas atau Gastroskopi di RSUD Arifin Achmad, Pekanbaru.

\section{Metode}

Studi prospektif pada pasien yang dijalani pemeriksaan endoskopi saluran cerna atas di rumah sakit Umum Daerah Arifin Achmad, Pekanbaru dari bulan Agustus 2007 sampai dengan Agustus 2011. Delapanpuluh tujuh pasien telah dilakukan endoskopi saluran cerna atas berbagai indikasi, dan juga dilakukan biopsi jika diperlukan yang diberikan oleh ahli patologi anatomi. Endoskopi saluran cerna dilakukan dengan alat Olympus Evis Exera II CV- 180 tahun 2007, dengan midazolam $0,2 \mathrm{mg} / \mathrm{kgbb}$ intravena sebagai sedasi, dan lidokain spray untuk anastesi lokal pada rongga mulut.

\section{Hasil}

Pada Tabel 1 tertera karakteristik pasien yang dilakukan endoskopi saluran cerna atas, atau gastroskopi dengan usia terbanyak antara 5-10 (48,3\%) tahun, laki-laki lebih banyak dari perempuan; $56,3 \%$ dan $43,7 \%$ dengan suku melayu lebih dominan $(37,9 \%)$.

Indikasi terbanyak dilakukan endoskopi saluran cerna atas berupa muntah darah $31,0 \%$, diikuti sakit perut berulang $26,4 \%$, dan muntah persisten $25,3 \%$ (Tabel 2).

Tabel 1. Karakteristik pasien $((\mathrm{n}=87)$

\begin{tabular}{lcc}
\hline Karakteristik & $\mathrm{n}$ & $\%$ \\
\hline Umur (tahun) & & \\
$0-5$ & 17 & 19,5 \\
$5-10$ & 42 & 48,3 \\
$10-15$ & 28 & 32,2 \\
Kelamin & 49 & 56,3 \\
Laki - laki & 38 & 43,7 \\
$\quad$ Perempuan & & \\
Suku & 33 & 37,9 \\
Melayu & 21 & 24,1 \\
Minang & 13 & 14,9 \\
Jawa & 12 & 13,8 \\
Batak & 3 & 3,5 \\
Nias & 2 & 2,3 \\
Sunda & 2 & 2,3 \\
Banjar & 1 & 1,2 \\
Aceh & & \\
\hline
\end{tabular}

Tabel 2. Indikasi endoskopi saluran cerna atas

\begin{tabular}{lcc}
\hline Indikasi & $\mathrm{n}$ & $\%$ \\
\hline Muntah persisten & 22 & 25,3 \\
Sakit perut berulang & 23 & 26,4 \\
Muntah darah & 27 & 31,0 \\
Sakit perut akut & 9 & 10,3 \\
Lain lain & & \\
Benda asing & 3 & 3,5 \\
Splenomegali & 2 & 2,3 \\
Sakit menelan & 1 & 1,2 \\
\hline
\end{tabular}

Tabel 3. Hasil temuan endoskopi saluaran cerna atas (gastroskopi) berdasarkan indikasi

\begin{tabular}{lc}
\hline Hasil endoskopi & $\mathrm{n}$ \\
\hline Muntah persisten $(\mathrm{n}=22)$ & 20 \\
Gastroesphageal refluk & 1 \\
Hiatal hernia & 1 \\
Normal & \\
Sakit perut berulang $(\mathrm{n}=23)$ & 5 \\
Esofagitis & 11 \\
Gastritis hiperemis & 3 \\
Ulkus gaster & 3 \\
Duodenitis & 1 \\
Normal & \\
Muntah darah (n=27) & 2 \\
Esofagitis & 9 \\
Gastritis erosive & 10 \\
Verises esofagus & 1 \\
Tumor duodeni & 1 \\
Ulkus duodeni & 4 \\
Ulkus gaster & \\
Sakit perut akut (n=9) & 6 \\
Gastritis akut & 2 \\
Duodenitis akut & 1 \\
Normal & \\
Pada indikasi lain & 3 \\
Corpus alienum & \\
Uang crin (ektraksi) & \\
Splenomegali & \\
$\quad$ Normal & \\
Sakit menelan & \\
$\quad$ Massa laring & \\
\hline
\end{tabular}

Pada Tabel 3 didapatkan bahwa berdasarkan pemeriksaan patologi terdapat Gastroesophageal refluk 20/22 pasien dengan muntah persisten dan hanya $1 / 22$ berupa hiatal hernia. Hampir setengah atau 
11/23 pasien gastritis hiperemis temuan endoskopi pada pasien sakit perut berulang. Disamping itu, terdapat $5 / 23$ esofagitis, $3 / 23$ ulkus gaster, dan $3 / 23$ duodenitis temuan endoskopi lainnya pada pasien sakit perut berulang. Terlihat varises esophagus 10/27 pasien sebagai penyebab terbanyak muntah darah kemudian gastritis erosive, dan ulkus gaster masing-masing 9/27 dan 4/27. Pada pasien dengan varises esofagus telah dilakukan ligasi varises dengan band secara berulang melalui tindakan endoskopi saluran cerna atas. Pemeriksaan patologi anatomi pada pasien dengan tumor duodeni didapatkan hasil berupa Adenoma bulbus duodeni. Sakit perut akut $6 / 9$ pasien disebabkan oleh gasrtitis akut dan sisanya disebab karena duenenitis akut 2/9.

Indikasi lainnya dilakukan endoskopi saluran cerna atas berupa corpus alienum, di tenggorokan, kemudian karena splenomegali yang tidak diketahui penyebabnya, dan terdapat satu pasien karena gangguan menelan. Dari hasil pemeriksaan endoskopi pada pasien dengan gangguan menelan didapatkan adanya massa di laring dan dilakukan biopsi dengan hasil pemeriksaan patologi anatomi berupa Papiloma skuamosa Laryng. Dari 87 pasien yang dilakukan pemeriksaan endoskopi saluran cerna atas, telah dilakukan sebanyak 45 biopsi pada saat pemeriksaan dengan hasil $40(88,9 \%)$ di antaranya terdapat kuman Helicobacter pylori

\section{Pembahasan}

Indikasi paling banyak dilakukan endoskopi saluran cerna atas pada penelitian kami berupa muntah darah. Berbeda dengan keluhan utama pada pasien anak berupa sakit perut berulang. ${ }^{3}$ Pada penelitian kami, sakit perut berulang merupakan indikasi kedua terbanyak dilakukannya endoskopi saluran cerna atas. Insiden perdarahan saluran cerna atas dilaporkan oleh El Mouzan $\mathrm{dkk}^{4}$ sebesar 5\% dengan umur 5-18 tahun. Perbandingan laki-laki dan perempuan sebesar 7:1. Penelitian Sabir $\mathrm{dkk}^{5}$ di Sudan, didapatkan 40\% indikasi pemeriksaan gastroskopi berupa hematemesis, $17,5 \%$ berupa muntah berulang, dan $10 \%$ berupa sakit perut berulang.

Penyebab utama dari perdarahan usus halus pada anak adalah divertikulum meckel yang berisi mukosa ektopik gaster atau pánkreas dan dapat terjadi ulserasi. ${ }^{6}$ Duplikasi merupakan penyebab kedua tersering perdarahan usus halus pada anak. ${ }^{7}$ Helicobacter pylori dapat menyebabkan ulserasi gastroduodenal, tetapi gambaran lesi noduler yang difus lebih sering ditemukan pada anak. ${ }^{6}$ El Mouzan $\mathrm{dkk}^{8}$ melaporkan dari 15 anak yang dilakukan endoskopi didapatkan 13 di antaranya $(87 \%)$ positif $H$. Pylori. Esofagistis karena refluks yang berat pada esofagus dapat disebabkan karena penyakit neuromuskular, trauma mekanik karena benda asing, dan trauma kimia karena tertelan bahan kaustik, obat-obatan, dan infeksi. Varises esofagus pada anak disebabkan hipertensi portal baik intrahepatik maupun ekstrahepatik. Trombosis vena splanikus dengan vena portal akan menyebabkan terjadinya varises esofagus. ${ }^{9}$ Kelainan vaskular dan duplikasi saluran cerna merupakan penyebab lainnya yang jarang ditemukan pada anak. ${ }^{6}$

Pada penelitian kami, Helicobacter pillory ditemukan pada 40 sampel dari 45 sampel yang dilakukan biopsi atau hampir $89 \%$ positif. Tidak berbeda dari penelitian di Sudan, dari 200 sampel yang dilakukan biopsi didapatkan Helicobacter pillory pada 165 sampel atau hampir 92\%. ${ }^{5}$ Sedikit studi pada anak yang menggunakan multiband ligator untuk ligasi varises esofagus. ${ }^{910}$ Kerner dkk mendapatkan bahwa penggunaan multiband ligator terjadi obliterasi atau hilangnya varises pada 26 pasien dari 28 pasien dalam dua kali sesi ligasi dengan komplikasi minimal. Pada studi tersebut penggunaan multiband ligator karena secara teknik mudah, dan aman pada anak. ${ }^{9,10}$.

Pemeriksaan endoskopi saluran cerna atas merupakan pemeriksaan non invasif yang lebih sensitif dan spesifik dan direkomendasikan untuk diagnosis infeksi Helicobachter pillory pada anak. ${ }^{11,12}$ Pada penelitian kami, dari 87 pasien yang dilakukan pemeriksaan endoskopi saluran cerna atas hanya 3 pasien yang tidak ditemukan kelainan secara endoskopi yang terdiri 1 pasien pada masing masing indikasi berupa muntah persisten, sakit perut berulang, dan sakit perut akut, sedangkan 84 pasien lainnya didapati kelainan secara endoskopi saluran cerna atas.

Pemeriksaan endoskopi saluran cerna atas merupakan indikasi pada pasien anak secara selektif dengan keluhan muntah persisten, sakit perut berulang, dan sakit perut akut, terlebih lagi pada pasien dengan muntah darah dan tertelan benda asing. Dari 27 pasien dengan muntah darah setelah dilakukan pemeriksaan endoskopi saluran cerna atas, didapati kelainan pada keseluruhan pasien. Berbeda dengan penelitian Quak $\mathrm{dkk}^{13}$ yang mendapatkan 29 pasien muntah darah ternyata 8 pasien tidak ditemukan kelainan. 


\section{Kesimpulan}

Endoskopi saluran cerna atas pada anak merupakan pilihan diagnostik dan terapeutik yang aman bagi pasien anak apabila dilakukan secara selektif atas indikasi yang tepat.

\section{Daftar pustaka}

1. Laajam MA, Al Mofleh IA, Al FalehFZ, Al Aska AK, Jessen K, Hussain J.Upper Gastrointestinal endoscopy in Saudi Arabia: analysis of 6386 procedures medicine. An International J Med 2011;66:121-5.

2. Ranjbar SA dan Torabinejad MH. Diagnostic endoscopy in children of two months to 15 years of age. Am J Applied Sci 2009 ;6:1812-4.

3. Apley J. The child with abdominal pains. London : Blackwell Scientific Publications; 1975.

4. EL Mouzan MI, Assiri AMA, Al Herbish AS, Al Sohaibani MO. Endoscopic duodenal biopsyin children. The Saudi J Gastroenterol 2006;12:31-3.

5. Sabir OME, Gadour MOEH. Upper gastrointestinal endoscopy in Sudanese infants and children. Sudan JMS 2007;2:91-5.

6. Hamoui N, Docherty SD, Crookes P F. Gastrointestinal hemorrhage the surgeon absolute. Emerg Med Clin N Am 2003;21:1017-56.

7. Chaibou M, Tucci M, Marc-Andre D, Farrel CA, Prroulx F, Lacroix J. Clinically significant upper gastrointestinal bleeding acquired in a pediatric intensive care unit : aprospective study. Pediatrics 1998;102:933-8.

8. El Mouzan MI, Assiri AMA. Peptic Ulcer Disease in Children and Adolescents. J Trop Pediatr 2004;50:32830 .

9. Zargar SA, a javid G, Khan BA, Yattoo GN, Shah Ah, Gulzar GM, dkk. Endoscopic ligationsclera compared with scleroterapi for bleeding esophageal, varices in children with extrahepatik portal venous obstruction. Hepatol 2002;36 :666-72.

10. Mckiernan PJ, Beatb SV, Davison SM. A prospective study, of ensdocopic esophageal variceal ligation using a multiband ligator. J Pediatr Gastrointestinal Nutr 2002;34:207-11.

11. Veres G, pehlivanoglu E, Helicobacter pyloriinfection in pediatrics. Helicobacter 2007; 12:38-44.

12. Oderda G, Rapa A, Bona G. Diagnostic tests for childhood helicobacter pylori infectio :invasive, non invasive or both. J Pediatr Gastroenterol Nutr 2004;39:482-4.

13. Quak SH, Lam SK, Low PS. Upper gastrointestinal endoscopy in children. Singapura Med J 1990 ;31:123-6. 